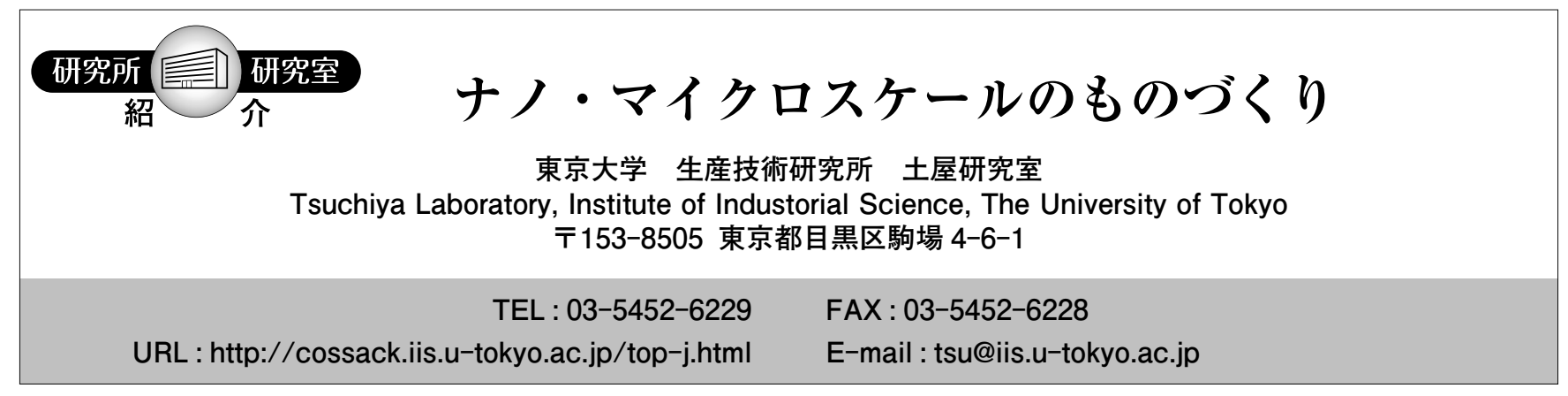

\section{1. 研究室の概要}

当研究室が所属する東京大学生産技術研究所は, 1949 年に東京大学第二工学部の後継として設立され, 今年で 60 周年を迎えました。所在地は, 当初の千葉市弥生町か ら，1962 年に港区六本木へ，2001 年に目黒区駒場へと移 転して現在に至っています（図 1)。研究組織は 5 部門か ら構成され, 途中で分離した航空宇宙部門をのぞく工学系 の広い分野を研究領域としています。生産技術研究所は, 大学に附置された研究所としては日本最大の研究所で, 現 在, 教員が約 130 名, 研究 - 技術職員が約 150 名, 大学院 学生が約 650 名, 受託研究員, 共同研究員, 博士研究員が 約 120 名在籍しています. また, 複数の分野の研究者が密 接に協力体制を組むことによって大型の共同研究やプロジ エクト研究を行い, それらを実施する研究センター等を多 数立ち上げています.

当研究室は 2005 年 12 月に設立し, 上記 5 部門中の機 械・生体系部門に所属して, 後述するように主に微細加工 とその周辺技術を研究しています。

\section{2. 専 門 (分 野)}

当研究室では, ナノ・マイクロスケールのものづくりを 基本テーマとしており，それに関連して，大きく分けて， 微細形状を創成する微細加工技術, 被加工物を顕微鏡下で 扱う微細組立技術，およびそれらを利用したマイクロデバ イスの 3 領域について研究を行っています.

ものづくりのためには，まずは形を作ることが必要にな ります。要求機能を実現する形状や材質を分析し, それを

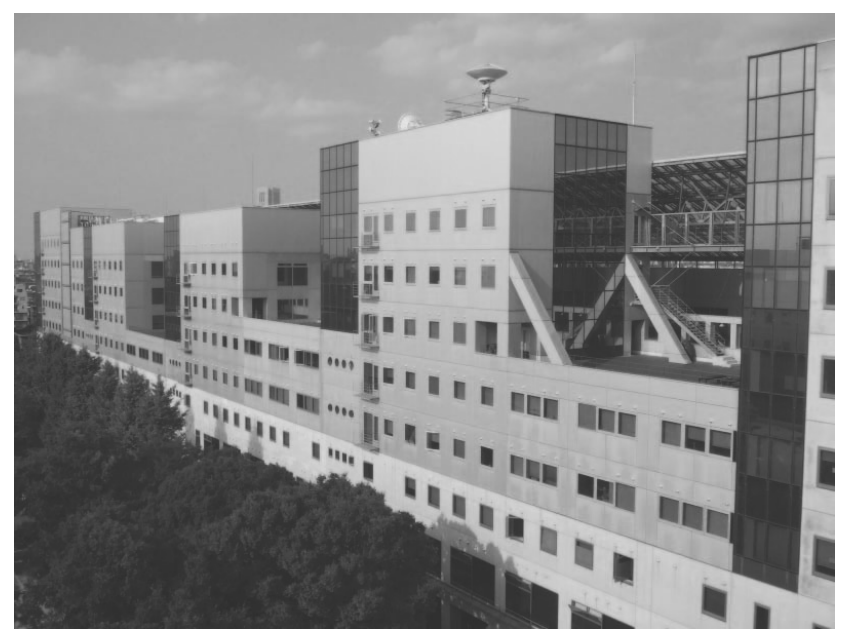

図 1 東京大学生産技術研究所の外観
作るための加工技術やプロセスを研究しています。次に， 加工した微細構造がデバイスとして機能を発揮するために は, 組立・接合・配線などの実装技術をはじめ, 調整, 検 査, 分解などさまざまな操作, 作業が必要となります。そ れを可能とするシステムの構築や, エンドエフェクタの開 発を行っています。これらの技術でマイクロデバイスを開 発し，付加価值の高い分野での実用を目指しています.

\section{3. 研究室のメンバー構成}

2009 年 4 月現在の研究室のメンバー構成は, 准教授 1 名, 技術員 1 名, 秘書 1 名, 準博士研究員 1 名, 特任研究 員 2 名, 大学院学生 3 名, 研究実習生 1 名の合計 10 名之 なっています (図 2). 小規模な研究室ですが, その分一 人ひとりの果たす役割が大きいため, メンバーそれぞれが 責任とやりがいを感じて日々の生活を楽しんでいます.

その一方, 研究室に求められるものは研究だけではない と考え, 教育活動やレクリエーションも積極的に行ってい ます。ささまざまな工場見学ツアーや専門外の分野のセミナ 一なども年に数回は開催しています, また, 研究室合宿や バーベキューなどのイベントにも力を入れて, これらの活 動を通して，人とのつながりを大事にするように心がけて います，その甲斐あってか, 宴席などには外からの客が頻繁 に参加して, とてもアットホームな需囲気ができています。

\section{4. 研究 テーマ}

\section{1 微細形状の射出成形に関する研究}

当研究室では, ナノインプリンティングのために, 微細 形状を射出成形で転写する技術を開発しています。しか

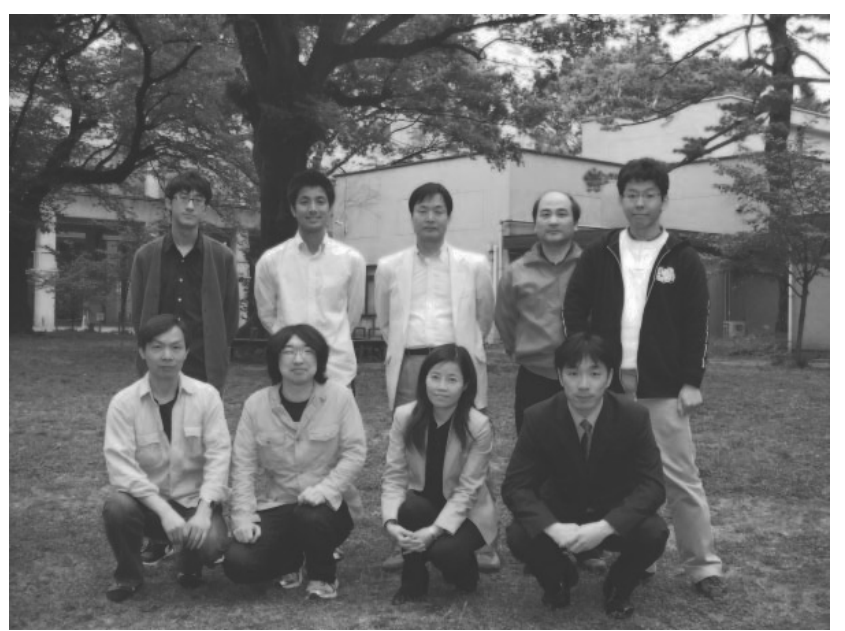

図 2 研究室のメンバー 

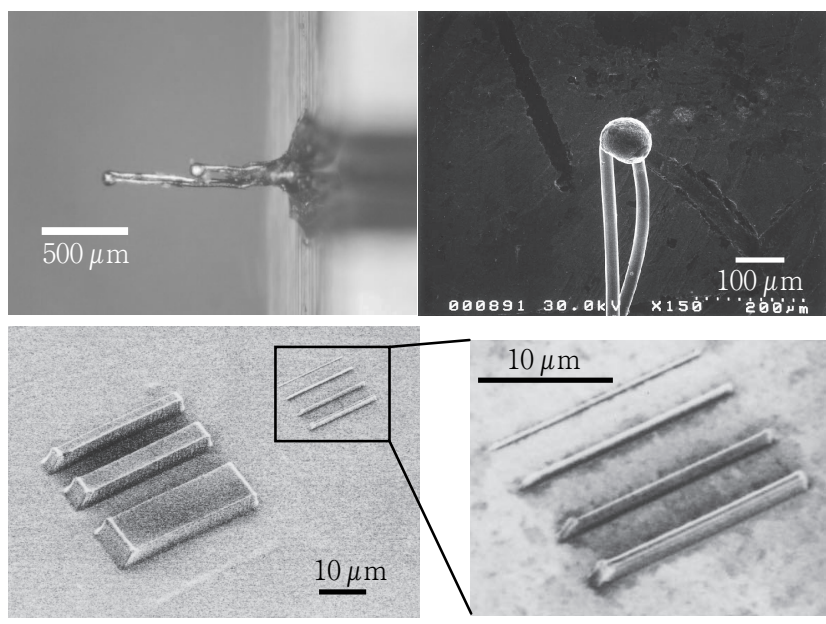

図 3 樹脂温度を測定するマイクロ熱電対アレイ(上)，転写された 微細形状（下）

し，微細な凹凸に充填される前に樹脂が固化して，形状が 転写されないという問題が生じます。そのため, 転写形状 の寸法, 射出圧力, 樹脂温度, 金型温度などの諸条件に注 目して，微細な形状を転写できる条件を検討しています. 実験のために, 樹脂温度を直接測定する直径 $25 \mu \mathrm{m}$ の熱 電対や，金型内部の熱移動を測定する熱流束センサを新た に開発しました（図３上）。

実験の結果, 図 3 下のような $1 \mu \mathrm{m}$ 程度より小さい形状 を転写する場合, 金型温度が高いことだけが重要で, 射出 圧力の影響はほとんどないことがわかりました。つまり， 樹脂の流動性だけが支配的だということです。また，この とき形状が微細であるほど樹脂が速く冷えることもわかり ました。

この他，金型自体を直径 $30 \mathrm{~mm}$ と小形に設計して，急 速加熱・急速冷却することで, 成形の時間を短縮する試み も行っています.

\section{2 顕微鏡下での微細構造物ハンドリングシステム}

微細な構造物を組立・接合するために, 観察しながら作 業を行うシステムを開発しています。これまでに, 電子顕 微鏡下で動作するマニピュレータを開発し, 例えば染色体 の内部構造を解明するために, 染色体を機械的に破断させ て断面を観察しました。 また, 次世代デバイス材料として 注目される酸化タングステンナノワイヤに直接荷重を与え て, ヤング率や破断強度, 破壊モードなどを調べています (図4).

その他にも, 卵子の変形を抑えてピペットを刺入する顕 微授精システムや, DNA ファイバを伸長, 切断, 回収す るサージェリシステムの開発も行っています。毛れぞれの 作業内容や対象物に応じて, 顕微鏡やマニピュレータなど を適宜変更し、エンドエフェクタを新たに開発すること で, 要求機能を満たすシステムを個別に構築することがで きます。

\section{3 血管のコンプライアンスに関する研究}

医療デバイスとして接触式の血管形状センサの開発を行 っています，主に冠動脈をターゲットとして，血管のコン
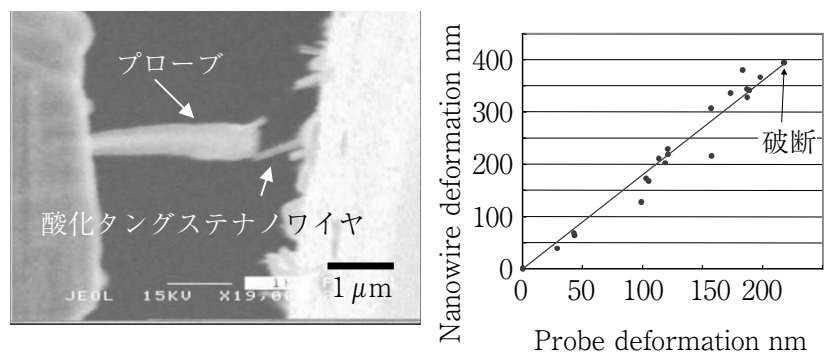

図4 酸化タングステンナノワイヤの破断実験の様子（左），プロー ブ・ワイヤの変形量の関係（右）
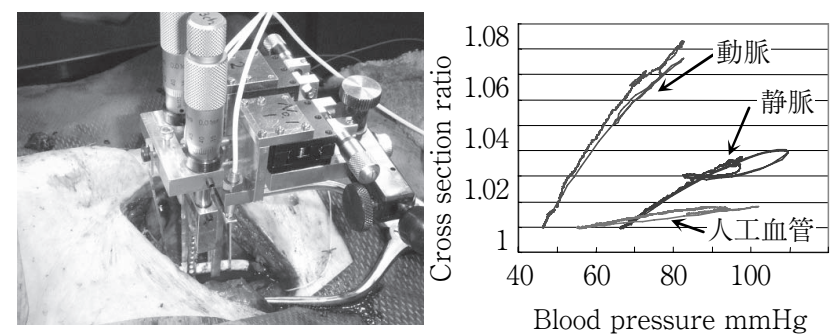

図 5 血管形状センサを用いた動物実験の様子（左）と血圧と血管 断面積の関係（右）

プライアンスを測るのが目的です，冠動脈が詰まると心筋 梗塞になりますが, 血管自体のコンプライアンスと詰まり やすさとの間に相関があると指摘されています。しかし， コンプライアンスの定量的な評価指標も測定器もないとい う問題があります。そこで，心拍に対する血管の伸縮を正 確に測って，その応答から血管のコンプライアンスを評価 する装置を開発しました。図 5 左が試作したセンサの写 真です，血管表面の動きを縦横 2 軸の接触子でとらえて, その接触子の動きを渦電流センサで測定します.

実際の測定結果から血管の断面積を計算して, 血圧に対 する応答をプロットしたのが図 5 右のグラフです。ブタの 動脈・静脈と人工血管について測定した結果, 動脈は非常 に柔らかく, 人工血管は硬くてほとんど伸びないというこ とが分かりました．また，動脈と静脈は上に凸のカーブを 描き，伸びるほど硬くなる非線形のコンプライアンスをも っていることが分かりました。 この非線形性が, 血管が詰 まらないための重要な要素になっているのではないかと考 え, さらに研究を進めています。

\section{5.おわりに}

当研究室は, ナノ・マイクロスケールのものづくりをコ ンセプトとして, 今後も微細加工技術, 組立実装技術, マ イクロデバイスの 3 領域の研究を進める予定です，優れた 技術を生み出すには，優れた構想とともにそれなりの年月 を要します。当研究室は設立してからまだ日も浅いため, 焦らず慌てず諦めず，根気よく取り組んで，世の中の役に 立つ技術を作ることを目指します, それと同時に, 研究室 の活動を通して若い技術者, 研究者を育てて世に送ること で，世の中に貢献したいと考えています。 